\title{
Consumers' Food Safety Knowledge and Practices During COVID-19 in Jordan: Web-based Survey
}

Eva Inam Al Zein ${ }^{1}$, MD, MPH; Amjad Rashaideh², BSc, MPH; Khaled Kheirallah ${ }^{3}$, PhD; Hala Khazally ${ }^{1}$, DVM, MSc; Mamoun Syaheen ${ }^{1}$, BSc

\footnotetext{
${ }^{1}$ Jordan Food and Drug Administration, Food Directorate, Domestic Food Safety Department, Amman, Jordan

${ }^{2}$ Jordan Food and Drug Administration, Food Directorate, Amman, Jordan

${ }^{3}$ Jordan University for Science and Technology, Medical School, Public Health Department, Irbid, Jordan
}

\section{Corresponding Author:}

Eva Inam Al Zein, MD, MPH

Jordan Food and Drug Administration

Food Directorate

Domestic Food Safety Department

Shafa Badran

Marj Al Faras

Amman, 11181/811951

Jordan

Phone: 165632000 ext 2347

Fax: 15105916

Email: eva.alzain@jfda.jo

\section{Abstract}

Background: In Western countries, several studies have reported changes in consumers' behaviors regarding food safety in response to the COVID-19 pandemic. The shared responsibility of food safety, between governments, food businesses, and consumers, has been well recognized and calls for extra preventive measures and recommendations to be introduced for food handlers, producers, and consumers. Little, however, is known about food safety in developing countries, including Jordan.

Objective: This study assessed the food safety knowledge and behaviors during the COVID-19 pandemic era in Jordan.

Methods: A web-based, self-administered questionnaire, published via the Jordan Food and Drug Administration website and social media platforms (March-July 2021), was utilized. The questionnaire assessed COVID-19 preventive measures (11 questions), food safety knowledge, (13 questions), and food safety practices (12 questions). Descriptive statistics were presented.

Results: In total, 969 respondents gave valid responses, of which 588 (60.7\%) were females, $325(33.5 \%)$ were 38-49 years old, $628(64.8 \%)$ were married, $623(64.3 \%)$ had college or bachelor degrees, $376(38.8 \%)$ were from the central region, 809 $(83.5 \%)$ were living in urban settings, and 313 (32.3\%) had a medical background. The mean (SD) food safety knowledge score was 8.34 (2.33; range $0-13)$. Mean food safety knowledge scores were significantly different $(P<.05)$ by age, marital status, education, field of study, training in food safety, employment status, monthly family income, and area of residence but not by gender and number of family members. Statistically significant correlations between mean knowledge scores and COVID-19 practice scores $(P<.001, \mathrm{r}=0.183)$ and food safety practice scores $(P<.001, \mathrm{r}=0.346)$ were detected.

Conclusions: Consumers seem to have adequate food safety knowledge and follow COVID-19-related preventive measures, which may transfer to better food practices and prevention of diseases, such as foodborne illnesses and COVID-19. Further studies and interventions in this regard are needed in Jordan.

(iproc 2022;8(1):e36617) doi: $\underline{10.2196 / 36617}$

\section{KEYWORDS}

food safety; COVID-19; knowledge; practices 
Edited by Y Khader; this is a non-peer-reviewed article. Submitted 19.01.22; accepted 19.01.22; published 07.02.22.

Please cite as:

Al Zein EI, Rashaideh A, Kheirallah K, Khazally H, Syaheen $M$

Consumers' Food Safety Knowledge and Practices During COVID-19 in Jordan: Web-based Survey

iproc 2022;8(1):e36617

URL: https://www.iproc.org/2022/1/e36617

doi: $\underline{10.2196 / 36617}$

PMID:

(CEva Inam Al Zein, Amjad Rashaideh, Khaled Kheirallah, Hala Khazally, Mamoun Syaheen. Originally published in Iproceedings (https://www.iproc.org), 07.02.2022. This is an open-access article distributed under the terms of the Creative Commons Attribution License (https://creativecommons.org/licenses/by/4.0/), which permits unrestricted use, distribution, and reproduction in any medium, provided the original work, first published in Iproceedings, is properly cited. The complete bibliographic information, a link to the original publication on https://www.iproc.org/, as well as this copyright and license information must be included. 